\title{
Problems of City Government
}

\author{
WiLLiam L. Betz \\ Mayor \\ Vincennes, Indiana
}

To speak to a group of public officials who plan and handle the down-to-earth problems of our state, counties, cities and towns, is an assignment which can not be taken lightly. I feel highly honored to have the opportunity to speak to you men on the vital subject of what Indiana cities need.

"Home Rule"- the right to run their own affairs, without too much legislative interference, is the greatest need of Indiana cities and towns.

It was Mayor Tom L. Johnson, of Cleveland and one of the country's greatest mayors, who said: "The most pressing of all civic problems is that of Municipal Home Rule." One of the worst popular misconceptions is that national government and politics are more important than local government and politics. It is just the reverse. Local politics is not only more vital but it is basic. It is the foundation upon which the whole structure rests. If it is not sound, then nothing built on it is sound. Your local officials in the counties and cities and towns were selected and elected by the people. They are close to the people. For 365 days and nights a year they are responsible, under oath, for the protection of the lives, property, health and safety of the people. And, Gentlemen, those are serious responsibilities.

It is hardly necessary to impress upon this learned group of practical men, who execute a large portion of the construction, maintenance and repair of the vital projects of our state, counties and cities, the importance of municipalities. No unit of government deals more intimately and frequently with the daily life of the majority of Americans than the municipality. It guards the citizen's home against burglary and fire; it protects him against disease; it looks to the purity of the water he drinks, the food he eats, and even the air he breathes. It conducts the schools where his children are educated. It builds his streets and sidewalks and keeps them clean. It lights the streets and alleys to prevent crime, immorality and accidents 
to the traveling public. It collects the garbage and trash. It provides facilities for his recreation. City government is at his side every second, day and night.

To be more concise, here are a few of the responsibilities of modern government which require scientific treatment and study:

Local, State and Federal Relationships

The Taxation Problem

Modern Police and Fire Protection

Public Health

Business and Utility Regtilation

Recreation

Streets and Traffic

Zoning and Building Codes

These are but a few of the many pactical problems which are today in the lap of every municipal official. Each of these responsibilities requires technical study and research and each one vitally affects the lives of the majority of citizens in Indiana. They cannot be solved with campaign promises, yet in every American city reckless promises impossible of fulfillment will be made in the coming campaign and many people will believe them.

In contradistinction to the problems of the present city, let us take a look at the past:

Fifty years ago there was no parking problem. A 20-mile ride was a day's trip.

Fifty years ago, there were few, if any, swimming pools. The boys here at Purdue and Lafayette and West Lafayette went swimming in the Wabash River-and many of them drowned.

Fifty years ago, sanitation was mostly an outdoor affair.

A hundred years ago city payrolls were small. But citizens were roused out of bed to go fight fires.

Two hundred years ago the largest city in America was less complex than the average small town of today. But sewage ran in open gutters and water was carried from the town pump or delivered by carts.

The years have brought machine age progress, and progress has often had a high price. If we were afraid of our new and heavy responsibilities, we municipal officials could throw up our hands and do nothing but bemoan the loss of the "good old days." We could forget about budgets, about future depressions and the spectre of atomic war on our cities. And in my particular case at Vincennes, and a few other cities in the state confronted with a like peril, we could shudder 
and do nothing against the mad floods of the Wabash that threaten the lives and property of our citizens. But one day, sooner or later, the city dwellers or their children would pay heavily for our complacency.

Our cities cannot discharge these new responsibilities of the present age without home rule and adequate finances.

It has been said that "Democracy will die at the local level if local government cannot continuously supply essential services of high quality at reasonable cost." If democracy fails in the cities, it fails in the state and in the nation. The safety of the American form of government, in the final analysis, rests on the soundness of the government in our municipalities and similar units. Our form of government is founded on the local level. When that local level fails, the whole structure topples.

Gentlemen, your Indiana cities are about to topple. In all seriousness, Indiana cities are on the way out - on the way out because they can no longer perform the governmental functions imposed upon them, or render the many essential services demanded by the people.

This crisis was brought about by the failure of the state, the parent, to provide financially for its children, the cities and towns. Neither will the state grant home rule authority to the cities to provide for themselves. Cities, as you well know, have no constitutional existence, even though many of them are older than the state or the national government. Indiana cities and towns are creatures of the state. They are performing the state's functions at the local level. Because of this, they have been termed "Miniature States". Indiana's cities' responsibilities are increasing year by year. Yet, when our cities come to the legislature, explaining their plight and seeking relief from the state, the parent, they receive scant consideration.

With the increased costs of local government, the city must use the means allowed it by the sta $e$, the worst of all revenue-raising bases, real estate taxation. The stite, however, may tax its citizens in any way it pleases within the linits of the constitution.

The State of Indiana is using this unlimited taxing power to the detriment of the cities. It is depriving the cities of many effective sources of revenue desperately needed to pay for the vitally necessary city services. In fact, the state has cornered many lucrative sources of income that rightfully belong to the cities. While the municipalities are the source of these millions taken by the state, the civil cities and 
towns of Indiana receive back but a paltry sum of their own money with which to serve their people.

Property tax can no longer carry the load for the cities, any more than the property tax could carry the load for the state. Property tax must be augmented by other forms of revenue.

Twenty years ago the total state revenue was about $\$ 53,000,000$ a year. Today it is nearly $\$ 300,000,000$ a year. During that time the city property tax has increased from about $\$ 23,000,000$ to $\$ 43,000$,000 . The state makes much ado about its aid to local government, claiming to return about $\$ 80,000,000$. Whatever money it returns, no such sum is returned to the civil cities and towns. With the increased return from the Motor Vehicle Highway Fund, together with two-thirds of the liquor license fees, there is only about $\$ 10,000$,000 returned to the 535 civil cities and towns. It is true that the school units have been receiving about $\$ 53,000,000$ a year, and this last "no tax increase" legislature granted the schools another $\$ 12,000$,000 , I understand. And yet, the school city tax in Indiana is higher than the civil city taxes.

We want the schools and its teachers to have sufficient funds. But over on the civil city side, policemen and firemen and street workers and garbage collectors, and many others are quitting city jobs because of insufficient pay. When the civil city's police and fire protection fail, when its sewage and garbage collection collapse, when its streets crumble and its drainage systems clog, and its street lights go out, as I saw them in Gary and many other Indiana cities in the early thirties, the schools will close.

About 70 per cent of the state's population live in its incorporated cities and towns. The people of those 535 cities and towns pay about 90 per cent of the state's income.

Three new taxes have been imposed upon the people by the State of Indiana in the last few years which return to the state over 100 million dollars a year. The civil cities and towns receive less than $\$ 2,000,000$ from these three new taxes, which is only two-thirds of the liquor licenses granted in the respective municipalities. The cities receive none of the $\$ 14,000,000$ liquor gallonage tax, though the cities have the additional burden and expense of the liquor traffic.

The taxpayers of Indiana's 535 cities and towns paid to the state in 1949 in just five taxes-gross income, excise, cigarette, motor vehicle highway fund and state property- $\$ 143,740,740$. From this sum they received back a total of only $\$ 9,399,902.53$, which was 
15 per cent of the MVH Fund and 66\%2/3 per cent of the liquor licenses in their respective communities. This means that the taxpayers of Indiana's cities and towns paid to the state-in just these five state-collected taxes-an average of $\$ 65.00$ per capita, and received back an average of $\$ 4.25$ per capita.

The civil cities and towns of Indiana receive back from the State about $\$ 1.00$ for every $\$ 15.00$ they pay in the aforementioned five-collected taxes.

In the session of the general assembly just closed, the Indiana Senate proposed a resolution to ask Congress to call a constitutional convention for the purpose of amending the Constitution of the United States to earmark a return of federal income taxes to all states in proportion to the amount of taxes they paid in. The amount asked was 25 per cent of all taxes paid in by Hoosiers.

The municipal league, representing Indiana's cities and towns, has for years advocated such legislation on the state level. If that provision had been applied to the gross income tax when it was enacted, the civil city taxes would only be half as much as they are today. The gross income tax raised about $\$ 10,000,000$ the first year after its enactment. Today it raises about $\$ 74,000,000$.

We support Indiana Senate's theory of getting some of the state's money back from the federal government. Only we believe the great state of Indiana should practice what it preaches. The state should apply this theory to its own cities and towns Charity begins at home, or, as we Americans say, "What's good for the goose is good for the gander."

At the last session of the legislature our cities and towns had hoped to get their greatest need granted, home rule and a fair share of their own money being poured into the state treasury in ever increasing millions. However, the cities were defeated in this program. Neither did they succeed, along with county officials and several powerful groups who foresaw the desperate need, in passing the gasoline tax increase to save Indiana's highways, county roads and city streets. Why do 30 states have a higher gas tax than Indiana, with many of them selling their gasoline for less? The motoring public in these other states pays no more for gasoline, and in some cases less, than they da in Indiana, but more of their gasoline dollar goes back on the highways than it does in Indiana. Many of these states have a tax two and three cents a gallon higher than Indiana, and yet they pay no more per gallon for their gasoline. For some unknown reason Indiana motorists are being shortchanged. 
I have tried in a simple way to show you the need of our Indiana cities and towns, which is home rule and a fair share of state collected funds.

In the last session we tried with several bills to obtain these objectives, but were unsuccessful. While we passed no home rule bills, yet, on the other hand, we were kept busy, very busy, defending ourselves. We had to fight on several fronts in order to hold the little home rule we now possess. Instead of gaining home rule, we had to fight off bills that would have made vicious in-roads on the pittance of home rule that has not yet been repealed. We didn't get home rule, but we still have our cities and towns, for which, under the circumstances, we are truly thankful.

Which reminds me of old man Diogenese, who, as you all know, went forth some 2,000 years ago with a lantern to find an honest man. A fellow met him the other day with his lantern still searching for an honest man. The man hailed Diogenese and said: "What luck, Old Man, haven't you yet found your honest man?" To which Diogenese replied: "No-but I still have my lantern."

We have not yet got the home rule we are fighting for but we still have our cities and towns. The legislatures haven't abolished them yet, which gives us hope. There's always another chance. And we shall keep on fighting! 